\title{
PENGARUH PENAMBAHAN EKSTRAK KAYU SECANG (Caesalpinia sappan L.) DAN MINYAK IKAN LEMURU SEBAGAI ADITIF PAKAN TERHADAP DAYA SIMPAN TELUR DAN KOLESTEROL TELUR PUYUH
}

\author{
Liana Indah Lestari ${ }^{1)}$, Anang Widigdyo ${ }^{2)}$, Nita Opi Ari $\mathrm{K}^{2)}$ \\ ${ }^{1)}$ Mahasiswa Program Studi Ilmu Ternak Fakultas Peternakan \\ ${ }^{2)}$ Dosen Program Studi Ilmu Ternak Fakultas Peternakan \\ UNIVERSITAS ISLAM BALITAR \\ Jl. Majapahit No. 04 Kota Blitar \\ Email: lianaindah28@gmail.com
}

\begin{abstract}
This research aimed is to determine the effect of Secang extract addition and sardinella fish oil as feed additive on eggs performance and production of quail. The 98 quails and 10 weeks divided into 4 groups with unequal replication using the completely randomized design. The treatment which are $P_{0}$ (based ration), $P_{1}$ (based ration $+0,2 \%$ secang extract $+4 \%$ sardinella fish oil), $P_{2}$ (based ration $+0,4 \%$ secang extract $+4 \%$ sardinella fish oil), $P_{3}$ (based ration $+0,6 \%$ secang extract $+4 \%$ sardinella fish oil). The parameters observed were length storage time of egg, egg cholesterol rate. Data were analyzed by ANOVA and Duncan's analysis. The results showed that Secang extract addition and sardinella fish oil were increase egg cholesterol $(P<0.05)$ and not significantly $(P>0.05)$ on length storage time of egg and production of quail.
\end{abstract}

Keywords: Caesalpinia sappan L., egg quality, Sardinella fish oil.

\section{PENDAHULUAN}

Meningkatnya populasi ternak burung puyuh menjadi indikasi banyaknya masyarakat yang berminat untuk memelihara dan mengonsumsi produk-produk yang dihasilkan ternak burung puyuh dengan kandungan gizi tinggi yakni daging dan telur. Adapun salah satu permasalahan yang menghambat proses pemeliharaan puyuh adalah disebabkan oleh bakteri dan virus. Dalam upaya pencegahan serangan bakteri atau virus tersebut, peternak umumnya memberikan antibiotik sintetik pada ternak. Antibiotik dapat membantu menekan pertumbuhan bakteri patogen. Namun, penggunaan antibiotik yang berlebihi akan berakibat buruk pada ternak, karena antibiotik tersebut akan menjadi residu yang bersifat karsiniogenik dan menyebabkan resistensi ternak terhadap jenis mikroorganisme patogen tertentu. Selain itu, antibiotik akan terbawa pada produk ternak yang dihasilkan, seperti daging dan telur, sehingga akan membahayakan bagi konsumen yang mengonsumsinya.

Salah satu upaya untuk meminimalisir terjadinya hal tersebut, maka diperlukan zat aditif alami sebagai pengganti antibiotik yang mampu meningkatkan produktivitas ternak tanpa memberikan efek pada ternak ataupun konsumen. Hal tersebut dapat dilakukan dengan penambahan ekstrak kayu secang. Kayu secang merupakan salah satu tanaman herbal yang dapat dimanfaatkan sebagai minuman maupun pewarna makanan alami. Hasil dari penapisan fitokimia serbuk kayu secang mengandung flavonoid, saponin, alkaloid, tanin, senyawa fenolik, triterpenoid dan glikosida (Kusmiati dkk., 2014). Senyawa flavonoid merupakan senyawa yang memiliki aktivitas antioksidan khususnya dalam menangkap radikal bebas. 
Aktifitas flavonoid dalam ekstrak kayu secang juga berperan sebagai antibakteri. Hal ini disebabkan karena kemampuan flavonoid berikatan kompleks dengan cairan ekstra seluler dan melarutkan protein serta berikatan komplek dengan dinding sel bakteri (Dinasari, 2009).

Permasalahan kedua berkaitan dengan pemeliharaan puyuh adalah perlunya penambahan komponen omega-3. Omega-3 ini berperan penting pada penurunan kadar trigliserida dalam darah dan dapat menurunkan kadar lemak serta kolesterol daging dan telur . Salah satu penghasil omega-3 yang banyak tersedia di Indonesia adalah minyak ikan lemuru. Ikan lemuru merupakan salah satu jenis ikan tropis yang mengandung komponen asam lemak omega-3 dalam jumlah yang cukup tinggi. Hal ini dikarenakan ikan lemuru di alam banyak memakan plankton maupun mikro alga yang banyak memproduksi komponen asam lemak omega-3. Kandungan omega-3 dalam minyak ikan lemuru berfungsi sebagai prekusor pembentuk tromboksan dan dapat meningkatkan jumlah oksigen dalam darah (Rusmana dkk., 2008) serta dapat digunakan untuk menurunkan kadar kolesterol (Handayani dkk., 2013).

Pada sisi lain penggunaan minyak ikan lemuru mempunyai kelemahan, yakni: menyebabkan oksidasi pada produk telur yang dihasilkan. Sehingga perlu adanya upaya untuk mengurangi daya oksidasi dari minyak ikan lemuru. Salah satu upaya tersebut adalah dengan menggunakan ekstrak kayu secang. Kandungan antioksidan pada kayu secang dapat menekan kemampuan oksidasi minyak ikan, sehingga dapat menambah daya simpan telur yang mengandung omega-3 sebagai akibat dari penambahan minyak ikan dalam pakan puyuh petelur. Penambahan dalam bentuk ekstrak kayu secang diharapkan dapat mengurangi kandungan saponin, sehingga tidak mengganggu pencernaan pakan dan pertumbuhan puyuh.

Oleh karena itu, penelitian ini perlu dilakukan untuk mengetahui pengaruh penambahan ekstrak kayu secang yang dikombinasikan dengan minyak ikan lemuru terhadap daya simpan telur, kadar kolesterol telur dan produktivitas puyuh dalam upaya menghasilkan produk hewani yang aman, sehat, dan terbebas dari residu antibiotik berbahaya.

\section{MATERI DAN METODE}

Penelitian ini dilaksanakan selama 4 minggu dengan menggunakan burung puyuh strain Autumn umur 10 minggu. Kandang yang digunakan merupakan kandang battery yang terbagi menjadi 14 kotak dengan ukuran masing-masing kotak 45 × 30 × $25 \mathrm{~cm}$ dan setiap kotak berisi 7 ekor burung puyuh. Kandang yang digunakan terbuat dari bahan bambu dengan alas kasa yang dilengkapi dengan peralatan tempat minum dari nipple dan tempat pakan terbuat dari paralon. Pakan yang digunakan menggunakan pakan formulasi sendiri (self mixing) yang kandungan proksimatnya sesuai dengan Standar Nasional Indonesia untuk pakan burung puyuh periode layer. Kandungan proksimat pakan tersebut dijelaskan pada Tabel 1. 
Tabel 1. Komposisi dan Kandungan Proksimat Pakan Basal

\begin{tabular}{|c|c|c|c|c|c|c|c|c|c|c|}
\hline Bahan Pakan & \% bahan & EM & PK (\%) & LK (\%) & SK (\%) & $\mathrm{Ca} \mathrm{( \% )}$ & $\mathbf{P}(\%)$ & Lys (\%) & Met(\%) & Cys(\%) \\
\hline Jagung kuning & 50 & 1685 & 4.25 & 1.95 & 1 & 0.01 & 0.05 & 0.13 & 0.09 & 0.09 \\
\hline Bungkil kedelai & 15 & 336 & 6.45 & 0.14 & 0.9 & 0.05 & 0.04 & 0.4 & 0.093 & 0.1 \\
\hline Tepung ikan & 7 & 198.1 & 3.5 & 0.63 & 0.14 & 0.39 & 0.2 & 0.23 & 0.07 & 0.05 \\
\hline MBM & 13 & 308.75 & 5.59 & 1.42 & 0.32 & 1.27 & 0.62 & 0.34 & 0.0897 & 0.09 \\
\hline Pollard & 8 & 104 & 1.08 & 0.32 & 0.8 & 0.01 & 0.03 & 0 & 0 & 0 \\
\hline $\mathrm{DCP}$ & 5.7 & 0 & 0 & 0 & 0 & 1.06 & 0.01 & 0 & 0 & 0 \\
\hline Premix & 0.25 & 0 & 0 & 0 & 0 & 0.04 & 0.01 & 0 & 0 & 0 \\
\hline DDGS & 0 & 0 & 0 & 0 & 0 & 0 & 0 & 0 & 0 & 0 \\
\hline minyak goreng & 1 & 86 & 0 & 0 & 0 & 0 & 0 & 0 & 0 & 0 \\
\hline DL metionin & 0.05 & 0 & 0.05 & 0 & 0 & 0 & 0 & 0 & 0.05 & 0 \\
\hline Imla & 100 & 2717.9 & 20.92 & 4.46 & 3.16 & 2.83 & 0.95 & 1.1 & 0.39 & .8 \\
\hline
\end{tabular}

Sumber: Berdasarkan hasil perhitungan.

Metode yang digunakan adalah metode percobaan menggunakan Rancangan Acak Lengkap (RAL) dengan 4 perlakuan dan banyaknya ulangan yang berbeda (Unequal Replication mengacu pada Vincent, 1991; Steel and Torrie, 1980; Astuti, 1980) dengan menggunakan puyuh umur 10 minggu. Perlakuan diberikan selama 6 minggu. Banyaknya ulangan dari masing-masing perlakuan yakni $\mathrm{P}_{0}$ sebanyak 3 ulangan, $\mathrm{P}_{1}$ sebanyak 3 ulangan, $\mathrm{P}_{2}$ sebanyak 4 ulangan, dan $\mathrm{P}_{3}$ sebanyak 4 ulangan.

Perlakuan pakan yang dilakukan sebagai berikut:

$\mathrm{P}_{0}$ : Pakan basal tanpa penambahan ekstrak kayu secang dan minyak ikan lemuru

$\mathrm{P}_{1}$ : Pakan basal $+0,2 \%$ ekstrak kayu secang $+4 \%$ minyak ikan lemuru

$\mathrm{P}_{2}$ : Pakan basal $+0,4 \%$ ekstrak kayu secang $+4 \%$ minyak ikan lemuru

$\mathrm{P}_{3}$ : Pakan basal $+0,6 \%$ ekstrak kayu secang $+4 \%$ minyak ikan lemuru

Penambahan kombinasi ekstrak kayu secang dan minyak ikan dilakukan dengan sistem kocor yang disesuaikan dengan level pemberian pakan puyuh. Variabel yang diamati meliputi daya simpan telur, kandungan kolesterol telur, konsumsi pakan, berat telur, produksi telur (HDP), massa telur, konversi pakan dan mortalitas. Data yang diperoleh dari penelitian ini ditabulasi dengan program Excel untuk selanjutnya dianalisa dengan menggunakan analisis kovarian (ANOVA) RAL ulangan tidak sama dan apabila terdapat perbedaan pengaruh yang nyata atau sangat nyata dilanjutkan dengan Uji Jarak Berganda Duncan (UJBD).

\section{HASIL PEMBAHASAN}

Tabel 2. Hasil Analisis Data Performa Telur dan Produktivitas Puyuh

\begin{tabular}{ccccc}
\hline \multirow{2}{*}{$\begin{array}{c}\text { Variabel } \\
\text { Penelitian }\end{array}$} & $\mathbf{P}_{\mathbf{0}}$ & $\mathbf{P}_{\mathbf{1}}$ & $\mathbf{P}_{\mathbf{2}}$ & $\mathbf{P}_{\mathbf{3}}$ \\
\cline { 2 - 5 } & $313,41^{\mathrm{a}}$ & $316,00^{\mathrm{a}}$ & $314,00^{\mathrm{a}}$ & $326,29^{\mathrm{a}}$ \\
\hline $\begin{array}{c}\text { Antioksidan } \\
\text { Telur* }(\mathrm{mg} / \mathrm{ml})\end{array}$ & $222,96^{\mathrm{a}}$ & $369,46^{\mathrm{ab}}$ & $499,88^{\mathrm{bc}}$ & $653,18^{\mathrm{c}}$ \\
\hline $\begin{array}{c}\text { Kolesterol } \\
\text { Telur** }(\mathrm{mg} / \mathrm{kg})\end{array}$ & & &
\end{tabular}

Ket: Angka dengan superskrip huruf yang sama pada baris yang sama menunjukkan tidak berpengaruh nyata tiap perlakuan, sedangkan pada baris yang sama dengan superskrip huruf yang berbeda menunjukkan beda nyata antar perlakuan pada taraf signifikansi $95 \%$.

* : Laboratorium FakultasTeknologi Pertanian Universitas Brawijaya Malang 
** : Balai Pengujian Mutu dan Sertifikasi Produk Hewan Bogor

\section{Daya Simpan Telur}

Dalam penelitian ini, daya simpan telur diukur melalui tingginya kandungan antioksidan yang terdapat di dalam telur dengan menggunakan telur pada produksi umur 15 minggu. Rataan kandungan antioksidan telur puyuh yang dihasilkan dalam penelitian ini adalah sebesar $317,81 \mathrm{mg} / \mathrm{ml}$. Hasil analisis keragaman menunjukkan perlakuan pada pakan burung puyuh tidak memberikan pengaruh yang berbeda nyata terhadap kandungan antioksidan telur burung puyuh $(\mathrm{P}>0,05)$. Memang tidak terdapat perbedaan secara statistik, tetapi secara deskriptif terdapat perbedaan dari tiap perlakuan. Rataan kandungan antioksidan dari masing-masing perlakuan secara berurutan yakni $\mathrm{P}_{0}=313,41 \mathrm{mg} / \mathrm{ml}, \mathrm{P}_{1}=316,00 \mathrm{mg} / \mathrm{ml}$, $\mathrm{P}_{2}=314,00 \mathrm{mg} / \mathrm{ml}$ dan $\mathrm{P}_{3}=326,29 \mathrm{mg} / \mathrm{ml}$. Rataan kandungan antioksidan terendah terdapat pada perlakuan $\mathrm{P}_{0}=313,41 \mathrm{mg} / \mathrm{ml}$, sedangkan kandungan antioksidan tertinggi terdapat pada perlakuan $\mathrm{P}_{3}=326,29 \mathrm{mg} / \mathrm{ml}$. Hal ini menunjukkan bahwa pada taraf penambahan EKS 0,6\% yang dikombinasikan dengan 4\% MIL merupakan perlakuan terbaik dalam peningkatan kandungan antioksidan dalam penelitian ini.

Kemungkinan dosis EKS yang ditambahkan kurang sehingga tidak berpengaruh pada kandungan antioksidan telur yang dihasilkan serta didapatkan kandungan antioksidan yang relatif sama. Pembatasan penambahan EKS dan MIL didasarkan pada pendapat yang menyatakan batas maksimal penambahan zat aditif pakan yakni sebesar $1 \%$. Sehingga batas maksimal yang diberikan pada penelitian ini sebesar 0,6\% EKS dan 4\% MIL. Pada sisi lain EKS merupakan produk herbal dan antibiotik alami sehingga dapat meminimalisir adanya efek samping yang dihasilkan. Hal tersebut dapat diaplikasikan dalam penelitian lanjutan dengan meningkatkan dosis pemberian EKS pada pakan puyuh petelur. Seperti yang diungkapkan oleh Rina dkk. (2012) bahwa kayu Secang merupakan sumber antioksidan alami. Sudah banyak penelitian tentang khasiat tanaman Secang, baik sebagai antimikroba, antioksidan, maupun zat pewarna alami.

Jigna dan Sumitra (2005) juga mengungkapkan penggunaan ekstrak dan komponen aktif secara biologi hasil isolasi dari tanaman banyak digunakan dalam pengobatan alternatif, hal ini atas pertimbangan menghindarkan efek samping dari resistensi mikroorganisme patogen terhadap antibiotika. Kandungan senyawa flavanoid dan polifenol pada ekstrak kayu secang berperan sebagai antioksidan yang dapat menghambat radikal bebas. Senyawa flavanoid berperan sebagai antiokasidan karena memiliki gugus hidroksil yang yang terikat pada karbon cincin aromatik sehigga dapat menangkap radikal bebas yang dihasilkan dari reaksi peroksidasi lemak (Dewi, Puspawati, Swantara, Asih, dan Rita, 2014).

Semakin tinggi kandungan antioksidan telur, maka dapat menekan terjadinya oksidasi dalam telur sehingga kualitas dan daya simpan telur dapat meningkat. Selama penyimpanan aktivitas antioksidan akan mengalami penurunan, hal ini ditunjukkan dengan nilai aktivitas antioksidan yang semakin menurun. Menurut Rachmawati (2009), antioksidan akan mengalami penurunan selama penyimpanan, hal ini dikarenakan pada penyimpanan suhu kamar, kondisi lingkungan tidak dapat dikendalikan seperti adanya panas dan oksigen. Kontak langsung dengan panas dan oksigen sangat berpengaruh pada penurunan aktivitas antioksidan.

\section{Kandungan Kolesterol Telur}

Dalam penelitian ini, kandungan kolesterol telur diukur dengan menggunakan telur pada produksi umur 15 minggu. Rataan kandungan kolesterol yang dihasilkan dalam penelitian ini adalah sebesar $378,37 \mathrm{mg} / \mathrm{kg}$. Hasil analisis keragaman menunjukkan bahwa 
perlakuan pada pakan burung puyuh memberikan pengaruh yang berbeda terhadap kadar kolesterol telur burung puyuh $(\mathrm{P}<0,05)$. Rataan kandungan kolesterol telur dari masingmasing perlakuan secara berurutan yakni $\mathrm{P}_{0}=222,96 \mathrm{mg} / \mathrm{kg}, \mathrm{P}_{1}=369,46 \mathrm{mg} / \mathrm{kg}, \mathrm{P}_{2}=499,88$ $\mathrm{mg} / \mathrm{kg}$ dan $\mathrm{P}_{3}=653,18 \mathrm{mg} / \mathrm{kg}$. Rataan kandungan kolesterol terendah terdapat pada perlakuan $\mathrm{P}_{0}=222,96 \mathrm{mg} / \mathrm{kg}$, sedangkan kandungan kolesterol tertinggi terdapat pada perlakuan $\mathrm{P}_{1}=$ $752,95 \mathrm{mg} / \mathrm{kg}$.

Apabila dibandingkan dengan perlakuan kontrol, maka perlakuan penambahan EKS dan MIL secara nyata dapat meningkatkan kandungan kolesterol telur. Hal ini tidak sesuai dengan yang dikemukakan Suripta dan Astuti (2007) dalam penelitiannya bahwa penambahan MIL berperan menurunkan kandungan kolesterol telur puyuh. Penurunan tersebut berkaitan dengan semakin meningkatnya omega-3 pada ransum yang mengandung MIL dan yang dijelaskan oleh Nurwahyuni (2006) kandungan flavonoid yang tinggi dapat menurunkan kadar kolesterol dan trigliserida di dalam darah. Hal ini disebabkan karena senyawa flavonoid dapat menghambat reaksi oksidasi kolesterol Low Density Lipoprotein (LDL).

Kemungkinan perlakuan pakan dengan penambahan EKS dan MIL tidak dapat menurunkan kolesterol dikarenakan efek perlakuan yang tidak secara langsung serta perlu adanya proses metabolisme dalam tubuh. Peningkatan kadar kolesterol telur juga dapat disebabkan oleh proses pembentukan kolesterol secara endogen karena kolesterol sangat dibutuhkan pada puyuh petelur dalam jumlah banyak untuk membentuk hormon steroid. Aviati dkk. (2014) menjelaskan bahwa pakan yang diserap di usus mengandung komponen antara lain karbohidrat, lemak, protein, dll. Zat-zat tersebut dipecah menjadi senyawa yang lebih sederhana kemudian melewati vena porta hepatica atau sistem limfatik menuju ke hati, kemudian diubah menjadi asetil KoA. Asetil KoA diubah menjadi senyawa trimester enam karbon, 3-hidroksi-3-metilglutaril CoA (HMG-CoA). Enzim HMG CoA reductase berperan mengubah $\beta$-OH- $\beta$-methylglutaril $\mathrm{CoA}$ menjadi asam mevalonate. Tingkat kedua, melibatkan perubahan HMG CoA menjadi skualen, suatu hidrokarbon asiklik yang mengandung 30 atom karbon. Tingkat ketiga, skualen dijadikan siklik dan diubah menjadi sterol dengan 27 atom karbon (kolesterol).

Seluruh reaksi skulen menjadi kolesterol berlangsung didalam reticulum endoplasma. Pengangkutan asam lemak dan kolesterol dari hati ke seluruh tubuh dalam bentuk lipoprotein (endogenus), kemudian di hati, asam lemak diresintesis menjadi trigliserida yang kemudian bergabung dengan kolesterol, posfolipid, dan protein menjadi Very Low Density Lipoprotein (VLDL) yang akan diangkut ke seluruh jaringan tubuh termasuk ke folikerl ovarium. Sehingga dengan adanya peningkatan kolesterol endogen dan salah satunya tersalur ke folikel ovarium akan menjadikan kadar kolesterol telur lebih tinggi.

\section{KESIMPULAN}

Penambahan EKS sampai taraf 0,6\% yang dikombinasikan dengan 4\% MIL memberikan pengaruh yang berbeda sangat nyata $(\mathrm{P}<0.05)$ pada kandungan kolesterol telur. Kandungan kolesterol telur semakin meningkat di setiap perlakuan dibandingkan dengan perlakuan kontrol, sehingga perlakuan EKS dan MIL tidak efektif untuk menurunkan kadar kolesterol telur puyuh. Penambahan EKS dan MIL dalam pakan puyuh petelur sampai taraf pemberian sebanyak 0,6\% EKS dan 4\% MIL tidak berpengaruh terhadap kandungan antioksidan telur sehingga tidak memberikan pengaruh yang berbeda terhadap daya simpan telur.

\section{SARAN}


Perlu dilakukan penelitian lanjutan mengenai EKS dan MIL sebagai zat aditif pakan puyuh petelur dengan dosis yang lebih tinggi sehingga dapat digunakan sebagai bahan pembanding terhadap penelitian yang telah dilakukan. Perlu dilakukan penelitian lanjutan mengenai pengaruh penambahan MIL terhadap kandungan omega-3 telur. Perlu adanya kajian lebih lanjut mengenai batas maksimal penambahan zat aditif pakan herbal dan sintetis sehingga dapat digunakan sebagai acuan dalam melakukan penelitian selanjutnya.

\section{DAFTAR PUSTAKA}

Achmanu, Muhaerlin, Salaby. 2011. Pengaruh Lantai Kandang (Rapat dan Renggang) dan Imbangan Jantan-Betina Terhadap Konsumsi Pakan, Bobot Telur, Konversi Pakan dan Tebal Kerabang Pada Burung Puyuh. Jurnal Ternak Tropika. 12(2) : 1-14.

Andayani, R. 2008. Penentuan aktivitas antioksidan, kadar fenolat total dan likopen pada buah tomat (Solanum Lycopersicum L). J. Sains dan Teknologi Farmasi 13: 17.

Aviati, V., S. M. Mardiati, dan Tyas R. S. 2014. Kadar Kolesterol Telur Puyuh Setelah Pemberian Tepung Kunyit Dalam Pakan. Buletin Anatomi dan Fisiologi. Maret 2014. Vol 22 (1): 58-64.

Dewi, N.W.O.A.C, Puspawati, N.M., Swantara, I.M.D., Astiti, I.A.R.A., Wiwik, S.R. 2014. Aktivitas Antioksidan Senyawa Flavonoid Ekstrak Etanol Biji Terong Belanda (Jalanum betaceum Syn) Dalam Menghambat Reaksi Peroksidasi Lemak Pada Plasma Darah Tikus. Cakrakimia. 2(1): 7-16.

Dhidhik, H. A, Zulfanita, Jeki M. W. W. 2016. Berat Telur, Indeks dan Volume Telur Puyuh (Coturnix-coturnix Japonica) Pengaruh Konsentrasi Sari Markisa (Passion fruit) dan Lama Simpan di Suhu Ruang. Prosiding Semnas Sains dan Entrepreneurship III Tahun 2016. Sains Terapan, 581-587.

Dinasari, E. 2009. Identifikasi Senyawa Metabolit Sekunder Dari Ekstrak Bunga Kecombrang (Nicolia speciosa Horan) Dan Uji Toksisitasnya Dengan Metode Brine Shrimp Tes. Skripsi. Jurusan MIPA Prodi Kimia Fakultas Seni dan

Handayani, L., Iriyanti, N., dan Yuwono, L. 2013. Pengaruh Pemberian Minyak Ikan Lemuru Terhadap Kadar Eritrosit Dan Tombrosit Pada Ayam Kampung. Jurnal Ilmiah Peternakan. 1(1): 39-46.

Hariana, A. 2008. Tumbuhan Obat dan Khasiatnya. Cetakan Kelima. Jakarta: Penebar Swadaya.

Hery, D., A. 2011. Performa Produksi Burung Puyuh (Coturnix coturnix japonica) Yang Diberi Pakan Dengan Suplementasi Omega-3. Skripsi. Departemen Ilmu Produksi Dan Teknologi Peternakan Fakultas Peternakan. Institut Pertanian Bogor.

Jigna Parekh, and Sumitra Chanda. 2007. Antibacterial and phytochemical studies on twelve species of Indian medicinal plants. Phyochemical, Pharmacological and Microbiological Laboratory, Department of Biosciences, Saurashtra University, Rajkot, India. African Journal of Biomedical Research, Vol. 10: 175 - 181.

Kusmiati, Dameria, dan Dody, P. 2014. Analisa Senyawa Aktif Ekstrak Kayu Secang (Caesalpinia sappan L.) Yang Berpotensi Sebagai Antimikroba. Seminar Nasional Teknologi Industri Hijau I Tahun 2014.

Nurwahyuni, A. 2006. Efek ekstrak daun sambunganyawa terhadap LDL dan Kolesterol HDL darah tikus diabetik akibat induksi streptozoin. Skripsi. FMIPA. Universitas Negeri Semarang.

Rachmawati, Rani, Made R. D., dan N. Luh Suriani. 2009. Pengaruh Suhu Dan Lama Penyimpanan Terhadap Kandungan Vitamin C Pada Cabai Rawit Putih (Capsicum frustescens). Jurusan Biologi Fakultas MIPA Universitas Udayana, Bali. 
Rina, O., Chandra, U. W., dan Ansori. 2012. Efektifitas Ekstrak Kayu Secang (Caesalpinia Sappan L.) Sebagai Bahan Pengawet Daging. Jurnal Penelitian Pertanian Terapan. 12(3): 181-186.

Rusmana, D., Dulatif, N., dan Happali. 2008. Pengaruh Pemberian Ransum Mengandung Minyak Ikan Lemuru Dan Vitamin E Terhadap Kadar Lemak Dan Kolesterol Daging Ayam Broiler. Jurnal Ilmu Trnak. Fakultas Petrnakan Universitas Padjajaran. 8(1): 19-24.

Sestilawarti. 2011. Pengaruh Pemberian Mikrokapsul Minyak Ikan Dalam Ransum Puyuh Terhadap Performa Produksi dan Kualitas Telur. Prodi Ilmu Ternak. Pascasarjana Universitas Andalas.

Shirly, K., Yuliani, Didik, T. 2009. Pengaruh Pemberian Rebusan Kayu Secang (Caesalpinia sappan L.) Terhadap Mencit Yang Diinfeksi Bakteri Escherichia Coli. Jurnal Farmasi Indonesia. Vol 4 (4): 188-198.

Suripta, H., dan P. Astuti. 2007. Pengaruh Penggunaan Minyak Lemuru Dan Minyak Sawit Dalam Ransum Terhadap Rasio Asam Lemak Omega-3 Dan Omega-6 Dalam telur Burung Puyuh (Coturnix coturnix japonica). J. Indon. Trop. Anim. Agric. 32(1) March 2007. 